УДК 821.163.03.091:81'255.4Франко I.

DOI: $10.30970 /$ sls.2017.66.2073

\title{
SOUTH-SLAVONIC ISSUES IN IVAN FRANKO'S WRITINGS
}

\author{
IVan TEPLYY
}

The Ivan Franko National University of Lviv, 1 Universytets'ka Str., 79000, Lviv, Ukraine The Department of Foreign Languages for Humanities e-mail: i_teplyy@yahoo.co.uk

The proposed subject-matter covers the following aspects, viz.: scholarly papers dealing with the issues in question, translated and translation studies works based on these issues, figurative analogies and other forms of implementing the foreignlanguage discourse actively elaborated and introduced by I. Franko. In view of this, a major issue of intertextuality arises.

The scholarly papers written mainly on the material of Serbian, Bulgarian, and Montenegrin literatures touch upon a number of issues, such as translation of T. Shevchenko's works into Serbian and Slovene, the kolomyika meter in Serbian and Ukrainian folk songs etc. This similarity, I. Franko maintains, is not accidental and it would be worth looking for its sources. The other issues include Serbian dumas and songs, new Serbian periodicals, Haiduk songs, Bulgarian works by M. Drahomanov, I. Franko's civic stance a.o. The correspondence matters here a lot too. All of this corroborates I. Franko's credo of life: "To be a man, an educated man, not to remain a stranger in any such question which constitutes the sense of human life" ("Speech at the $25^{\text {th }}$ Jubilee").

I. Franko's translated works in the field of South-Slavonic literatures is represented in four volumes of the 50-volume edition, viz. vols. 10, 25, 51 and 52, amounting to 6 authors, 15 works, 57 pages. This isn't, however, the whole story. One should add the creatively developed plots, subjects, particular works (See I. Franko's work "Surka", his interlinear rendition of the Proglas, prompting, decades later, D. Pavlychko's "translation-transfusion of this creation of genius", to quote from the latter).

In conclusion, the topic is multifaceted, requiring further generalizations, research, analyses of the translations, and offers a valuable material to elucidate the issue of I. Franko's creative method as translator, his linguistic personality, philosophical and cultural context of the activity.

Key words: Slavistics, translation, reception, intertextuality, creative development, figurative analogy, creative borrowing, interliterary connections, activity.

The above-mentioned problem envelops a number of dimensions, viz.: scholarly and critical papers touching upon the issues in question, translation and translation studies works based on this set of problems, figurative analogies and other forms of assimilating a foreign language text elaborated and actively implemented by I. Franko himself. Intertextuality counts here as well. 
Among the scholarly and critical papers written on the material of Serbian, Bulgarian and Montenegrin literatures, worthy of attention is, primarily, the following one: "Translations from Shevchenko into Serbian". The next paper, shorter (two pages only), published on the occasion of Yelysavethrad-based author Mykola B. Levyts'kyi's article merits attention on account of shedding light on the issue of the languages' similarities: "That the kolomyika meter is present in Serbian folk songs, I knew, as it is, earlier from V. Karadžić's collection ("Српске народне пјесме") ${ }^{1}[\ldots]$. That, taken rhythmically, is the same Serbian "youthful" song, only extended in the first half of the poem by one four-syllabic foot [...]. This similarity is not accidental and it would be worth looking for its sources" (Франко, 1981, 32, c.17), as well as the articles "Serbian Folk Dumas and Songs" (Франко, 1980, 26, c.51-59), "The New Serbian Monthly "Strazha" (Франко, 1980, c.94-95), volume 41 of this very series (Франко, 1984, 41, c.347), "From Bulgarian Folk Songs. Songs of the Haiduks" (Франко, 1977, с.73-85), "The Bulgarian University Affaire" (translation of the article by Professor Miletić with I.Franko's explanations regarding the proposed to him position of Professor in Sofia - "Dilo", №. 280. 27. XII. 1907)" (Ярема, 2006, c.147), "Bulgarian Papers by M. Drahomanov" (Франко, 1986, 46 (2), с.24-42) etc. I.Franko's correspondence matters here as well.

Franko's translation work in the realm of South-Slavonic literatures is represented by four volumes [Франко, 1977, т.10, c.86-108 (From Serbo-Croatian Folk Poetry); Франко, 1980, т.25, с.457-470 (From Serbian Literature); Франко, 2008, т.51, с.803-812 (From Montenegrin Literature); Vol.52, pp.727-728; 729-736 (From Serbian Folk Poetry; From Bosnian-Herzegovinian Poetry)], which totals to 3 authors, 12 works, 39 pages (Serbian literature), 2authors, 2 works, 8 pages (Bosnian-Herzegovinian poetry), 1 author, 1 work, 10 pages (Montenegrin literature) - 57 pages all in all. One should add here the poem "Surka" written on the motive of Bulgarian folk art, etc.

As far as prose is concerned, I. Franko has translated Hayduky [The Haiduks], in his own wording, "A sketch from the life of Montenegrins by Luka Jovović" (Йовович, 1898, c.113) "Here they mentioned before me Jolović - M. Holberg maintains - [...]. It is a Montenegrin writer who published his work in the "Luča" magazine. This is a poor village teacher. This is a beginner, this is the first work by Jolović. Why does I. Franko in 1898, when he was already a famous writer, translate this Yolović? Serbs and Montenegrins hardly know him. In only one work on Montenegrin literature did I find a mention of him. Yet I. Franko translated him. It is because he found in the works of Yolovich the unity of the international and national, which is an important moment in the history of culture" (Гольберг, 1989, с.298).

Another researcher - L. Hajduković - arrives at the conclusion that there are numerous stylistic deviations in the translation due to the use of inappropriate vocabulary, grammatical transpositions, particularly replacement of a singular by the plural etc., e.g. the sentence“jep joj је муж дроња и не сме јој узети на шиватке",where “дроња" denotes a "non-independent person", "nonentity" reads in the translation as follows: "for her husband walks in the shingles and dare not even buy her a needle". Or the word combination "дивљи ūoü", i.e. "untamed", "uncouth", where "дивљи" - "wild" in the sentence "да ти је муж дивљь йoü" [that your husband is uncouth (=savage, that's what he is) - I. T.] is reproduced as "your husband is a pagan oracle" (Хајдуковић, 2006, с.132). On the one hand, the entry of explications into the target text frees the reader from bad misunderstandings, on the other,

\footnotetext{
${ }^{1}$ Serbian Folk Songs (in Serbian).
} 
however, violates, in a way, the tempo and the rhythm of the work translated (Хајдуковић, 2006, c.134). Yet "дроња", besides, is also "ragamuffin, tramp". I. Franko was, this way, right too.

M. Holberg distinguishes one more aspect of I. Franko's Serbian interests - creative interaction: "Present-day comparative literary theory - he writes - relies on an understanding of a literary work as integrity, as artistic world, which has a profound human-studies meaning. It is important to remember the thesis on the anthropology of a belles-lettres work, that on a creative interaction, wherein enormous artistic energy embodied in the texts of culture manifests itself. This energy acts as a source of new creative impulses. Let us recall, at least, the inspirational role played by the South Slavonic and, above all, Serbian song in the creation of such things as Mykhaylo Chernyshenko by P. Kulish, Poem on the White Shirt by I. Franko, Vila Posestra [Fairy Sister-in-God] by Lesia Ukrayinka [...]. It is necessary, when studying Ukrainian-Serbian literary relations, to distinguish and take into account the three major aspects of the comparative study of literatures: literary contacts, genetic connections and typological convergences" (Гольберг, 2006, c.164-165).

Worthy of attention is an important yet infrequently mentioned in Translation Studies I. Franko's work "Translations from Shevchenko into the Serbian Language" (Франко, 1981, 32, c.14-15), its writing being caused by the publication of T. Shevchenko's three poems translated into Serbian and placed in the Croatian literary and scientific journal "Nada" (Sarajevo, 1895-1903). 1899. №9. (Франко, 1981, 32, с.468). This review was first published in the sixth volume of the journal "Literary and Scientific Herald" for 1899 (Франко, 1899, с.188-189). That Croatian journal whose name translates, according to I. Franko, as hope (isn’t it symbolic?) published later on (№10-12) another 9 poems by T. Shevchenko, all of them authored by the Croatian writer and translator August Harambašić (1861-1911), I. Franko's contemporary. It is worth underlining that the journal is Croatian, not Serbian, as the author of the article claims. The latter, properly speaking, is the target language here. The works in question are 1) Water's running, but not out / It will, though, after all; [Тече вода, але не чье / Истечьи посвема]; 2) Mighty wind-o, mighty wind-o, / To the sea your talk is [Вјетре бујни, Вјетре бујни/ Ти говориш с морем]; 3) What for dark eyes are for me / What for are dark brows [На ито мени ирне очи / Обрвице ирне]. "The translation has been very beautifully done by the Serbian poet August Harambašić" (Франко, 1981, 32, c.14) who, by the way, published, back in 1887, T. Shevchenko's collected works "Poetry Stories" ["Пјесничке приповијести"] in Zagreb (The literary and scientific society "Matica Hrvatska"). I. Franko called it beautiful (Франко, 1981, 32, c.14). "To show what Ukrainian poetry looks like in Serbian clothing, we are submitting the third translation, having changed some spelling for lack of Serbian cuttings in our printing house

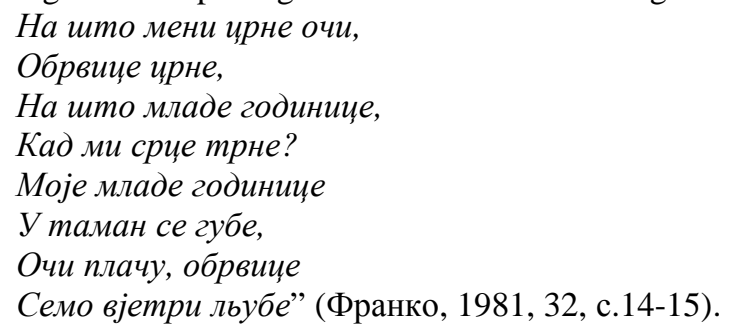

[What use are coal-black brows to me? / What use my hazel eyes? / Those years of happy maidenhood - / What joys from them arise? / Years of youth will pass away, / 
Vanish like the rose. / Eyes will weep and beauty fade, / With the wind it goes] (Taras Shevchenko, 2017).

In this connection, no ordinary, as we see it, interest is evoked by I. Franko's littleknown letter published by Ye. Stefanov (Septemvri (“Септември”) magazine, 1856). The letter is in Russian. Of importance to note is, in particular: "I would like to translate, with time, all of Botev and publish it with the portrait of Botev with biography, as a separate book, if only I could get his edition" (Дмитрук, 1958, c.136). The same letter communicates that "Mr. [Mister] Hnatiuk is ill, it seems dangerously; he left for Corfu. From your stories he translated something, but has not yet had it published. He may have failed to complete his work because, in spite of all his illness, he worked intensively until the last minute and took a lot of work along with him" (Франко, 1986, 50, с.219; Дмитрук, 1958, с.136). I. Franko appears here as the coordinator or organizer of a broader translation project. In the cited material, the talk is of the letter to P. Todorov, and the translation of his story Borba [The Struggle] as authored by V. Hnatiuk. The collection Studii in Honorem Ioannis Franko carries P. Todorov's Kaminnia [The Stones] (Дмитрук, 1958, c.135).

"Do you think - in a letter to M. Drahomanov (Lviv, Oct.6, 1893) - that the article by Shishmanov in the "Sbornik" [Collection] would be consistent with this goal [i.e. covered the issue on the present-day state and methods of folklore - I. T.]. In such a case I would undertake its translation (Франко, 1986, 49, c.420). And, though it never came to the publication (Франко, 1986, 49, c.723), a sacrifice like that is striking.

"Would you be so kind - as the letter to M. Drahomanov (Lviv, Apr. 5, 1892) goes to send me the Russian original of your work? This would be a great relief for me in reading, and would be of use later, perhaps, when I had to compile the Ukr[ainian] translation of your folklore works. The same holds true for Constantine and the Donkey of a Priest (Франко, 1986, 49, с.329). As far as the latter two papers are concerned, the point dealt with is M. Dragomanov's research in Bulgarian "Slavic Legends on the Birth of Constantine the Great and "Slavonic Variants of One Evangelical Legend" published in the edition: Collection of Folklore, Science and Literature, vols.2-5 (Франко, 1986, 49, c.681).

All in all, I. Franko has translated 13 lyric and epic Serbian songs into Ukrainian, 11 being published ${ }^{2}$, which is not so much as compared to the work of M. Starytskyi and Ya. Holovatskyi, but owing to the masterful translations I. Franko made a great contribution to the popularization of Serbian folk songs primarily in Galicia and Western Ukraine. The interest in the Serbian folk song particularly enlivened during the turbulent events in the Balkans, when the terrible bloody drama broke out there. The magazine "Druh" [The Friend], edited by I. Franko together with M. Pavlyk, publishes a review of the translations of Serbian folk songs by M. Starytskyi under the title Serbian Folk Dumas and Songs, evaluating them as "the first attempt at mastering by our language of the wonderful Serbian songs in all their entirety. In close connection with history, he considers the rich Serbian epic, focusing in detail on the two songs Бановић Страхиња [Banovich Strakhinia] and Бој на Косову (Косове поле) [Battle on Kosovo (Kosovo Field)] (Лаћак, 2006, c. 115).

The 50-volume I. Franko's collected works (chapter "From Serbo-Croatian Folk Poetry") carry ten translations, viz.: "St. Peter’s Mother" / Мајка светога Петра, "The

\footnotetext{
${ }^{2}$ Cf.: "I. Ya. Franko has translated only ten texts of Serbian folklore (emphasis ours - I. T.), the rest, regrettably, remained unfinished and are kept in the writer's manuscripts department" (Білоус Л. Л. 2006, 125) о "From Serbian literature he translated eleven folk songs and the story by L. Lazarević Hа бунару [By the Well - I.T] (Уметничко вече, 2006, с.208).
} 
Greatest Sins" / Нејвећи гријеси, "The Ungrateful Sons" / Неблагодарни син, "Betrayal of Gruy Novachenko's Wife" / Невјера љубе Грујичине, "Deacon Stepan" / ћакон Стефан и два анћела, "The Rich Havan's Wife" / ьуба богатого Гавана, "The Fire Serpent's Wife" / љуба змаја огњенога, "A Young Man Has Shot and Killed a Fairy" / Јунак вилу устриејли, "The Spinster and the Tsar" / Преља и иар, "Stojan Janković's Captivity" / Ройтво Јанковић Стојана (Франко, 1977, 10. с.86-108). All the translations were made ca. 1893-1895, which is, in particular, evidenced by the epistolary (Франко, 1986, 49, c.406). The following editions, viz. Вук. Српске Песме [Vuk. Serbian Songs], I, 208, 209, c.134-135; 135-140; 151; 171-172; II, 7-11, III, 7 (34-35), Караджич [Karadžić], 25 (168-172) (Франко, 1977, 10, 456-457). The poem "St. Peter's Mother" was first published in the "Life and Word" [“Жите і слово"] journal for the year 1895 p. pp.7-8, the same issue carrying the poems "The Greatest Sins" (p.8), and "The Ungrateful Sons" (pp.8-9). Book III of the same year's journal (pp.326-333) published the poem "Betrayal of Gruy Novachenko's Wife". All these translations have come out under the rubric "From Slavonic Folk Epic". The poems "Deacon Stepan" and "The Rich Havan's Wife" were first published by I.Franko in the book "Chytanka rus'ka dlia druhoyi kliasy shkil serednikh" [Ukrainian Reader for the Second Form of Secondary Schools]. Lviv, 1895, p. 60-63 and, respectively, 203-206, but the poems "The Fire Serpent's Wife", "A Young Man Has Shot and Killed a Fairy", "The Spinster and the Tsar" were only published after the translator's death (See the book "Inter-Slavonic Folkloristic Relations", 1963. Kyiv: Ukrainian SSR's Academy of Sciences Press, pp. 194; 194-195; 195). The autograph has been preserved (Central Scientific Library I, unit of conservation 4931, sheet 1 (poems 1, 2), 3 (poem 3)) (Франко, 1977, 10, c.456-457). The poem "Stojan Janković's Captivity" first saw the light of day in the Dnipro journal (1964, No.9, pp.141-143). The poem's autograph is under preservation in the Kyiv - based Central Scientific Library (I, unit of cons. 4931, sheet 46). This work belongs to the so-called uskok songs, constituting a separate cycle of SerboCroatian epic very close to the hajduk ones. Moreover, the Manuscripts Department of the V. Vernadskyi Central Scientific Library, National Academy of Sciences of Ukraine, stores autographs of a number of incomplete translations such as Zmiy-Korolevych [Serpent-Son of the King], Yak Yuh Bohdan svoyu zhinku prodav [How Yug Bogdan Sold His Wife] a.o. (Франко, 1977, 10, с.457).

"Serbian songs were of interest to I. Franko not only as a grateful object of scholarly research, a field for the free flight of his wise thought, they also interested him as a reader who had an impeccable aesthetic sense: "and in free minutes I revel in - writes I. Franko from Vienna where he was taking examinations for obtaining a doctor's degree - the Serbian songs by $\mathrm{Vuk}^{3}$ and translate from them what I come to like particularly" (Івашків 2006, с.106; Франко, 1986, 49, с.406). "The typological nature of plots and motifs in Ukrainian and Serbian folklore texts can be traced on the example of Franko's translation of the Serbian household song The Ungrateful Sons" (Івашків, 2006, с.105; Франко, 1977, 10, c.88-89). In this very letter, I. Franko - and that's of importance - shares his plans for the future as far as translations from the Serbian language are concerned: "I would like to translate and eventually publish all the Serbian legends, and, in particular, a selection of hajduk songs, left aside by Starytskyi; there being very interesting novella themes in some of them" (Франко, 1986, 49, с.406).

\footnotetext{
${ }^{3}$ Vuk Karadžić is meant.
} 
Bulgarian literature. I. Franko's translation work here covers 13 pages, 4 works (See the section "From Bulgarian Folk Songs (Франко, 1977, 10, c.73-85). There is a mention of it in the letter to M. P. Drahomanov (№126, L’viv, 10 Feb. 1889): “For further books, I would like to come to terms with you about the choice of folk songs of ours and those of other Slavs (I do not know if you saw in the Zerna [Grains] my attempt at translating Bulgarian hajduk songs, and what will you say about it?" (Франко, 1986, 49, с.195). The thing mentioned is a compilation of "four Bulgarian hajduk songs in the translation and with an introductory note by I. Franko, published in the collection Zerna. Literary and scientific supplement to "Bukovyna" for the year 1888, 1888. Chernivtsi, pp.30-41 (Франко, 1986, 49, c.622-623). The famous Bulgarian figure P. Atanasov very highly appreciated, albeit small in volume, but important in terms of significance the songwriting creativity of the Bulgarian people, viz. hajduk songs. "Ivan Franko sought to acquaint the public of Galicia with the life of Bulgaria. In 1888 Franko translated into Ukrainian four folk songs about the Bulgarian hajduks. It should be noted that Franko, who translated many works of world literature (more than 60 authors), made a wonderful translation [our italics - I. T.] of these songs. In the preface to them (this is a feature of I. Franko's creative method as translator] the Ukrainian writer introduced readers to the difficult life of the Bulgarian people during the Turkish yoke, origin and essence of the hajduks' phenomenon (Атанасов, 1956, с.32). It is not, however, the quantitative parameter only that matters (Дмитрук, 1958).

The most complete characterization of I. Franko as researcher of Bulgarian literature, translator of its works, in particular folklore is provided by N. Hryhorash (Григораш, 2007, c.89-107; see also: Кремпа, 1956, с.17-26; Гольберг, 1962, с.21-22). I. Franko, by the way, has been devoted most of the book space (p.89-107), among the personalities having contributed to the development of Literary-and-Bulgarian Studies such as Yu. Venelin, O.Bodians'kyi, M. Khalans'kyi, M. Drahomanov, I. Svientsits'kyi, I. Ohiyenko a.o.

The "Grains" [Zerna] magazine contains four hajduk songs from the collection of the $19^{\text {th }}$ c. Bulgarian writer and folklorist L. Karavelov (Liuben Karavelov, Folk Songs,vol. I, Russa, 1886) [in Bulgarian]. The source is kept in I. Franko's personal library at No. 987. MSS DPT, Institute of Literature, Academy of Sciences of the Ukrainian SSR. Bulgarian translations of some of Shevchenko's works done by Liuben Karavelov are offered here as well) (Гуць, 1966). I. Franko gave a title of its own to each of the songs translated, mirroring thus the plot of each one, e.g. "The Orphan Joins the Hajduky" (a feature of I. Franko's translation method as well). Before translating hajduk songs, I. Franko, as evidenced by the preface, had made a careful study of the Hajduks' paying particular attention to its social character. The Hajduk Songs article was published as a preface to translations of the Bulgarian songs made by I. Franko" (Гольберг, 1962, с.21).

Of great interest, too, is the fact of I. Franko's interlinear translation aiming at a research. The translation was destined, afterwards, more than half a century later, to provide a basis for another: "I found an article in Ivan Franko - a profound analysis of the Proglas [Проглас, 2017] ${ }^{4}$ - and, relying on the Franko's interlinear translation, made my own translation-transfusion of this creation of genius" [Павличко, 2006, c.8]. "Well ahead of his time, he put the scholars the question of the contextual approach, application of various research methods, implementation of the principles of complexity and interdisciplinarity,

\footnotetext{
${ }^{4}$ Proglas (Сyrillic Прогласъ; meaning Foreword) is the foreword to the Old Church Slavonic translation of the four Gospels. It was written by Saint Cyril in 863-867 in Great Moravia (present-day Moravia and Slovakia). Proglas is considered to be the first poem in literary Old Church Slavonic. [online] Available at: https://en.wikipedia.org/wiki/Proglas [Accessed 13 Spt. 2017]
} 
which later became the basis of Slavic methodology and methodology in general (Григораш, 2007, c.89). Ivan Franko's translations are a significant artistic achievement. The poet, with the unique colors of the Ukrainian word, conveyed the essence and beauty of Bulgarian Hajduk songs. This is due, first of all, to the talent of the writer, his impeccable knowledge of languages and a profound understanding of the works he touched by his pen. The Hajduk Bulgarian song of Franko did not lose its stern romantic and sublime tone, social acuteness. Franko's work at translating the Bulgarian hajduk epic was preceded by his artistic interest in Serbo-Croatian Hajduk and Uskok songs. The poet turned to them later, in the 1890s (Гуць, 1966). There is a copy of the Zerna [Grains] magazine, both with the interpreter's remarks, and with records from the collection of Bulgarian folk songs of the Miladinov brothers in the personal library of I. Franko (MSS Dpt., Institute of Literature, National Academy of Sciences of Ukraine). I. Franko will use them afterwards in his work on the fundamental paper "Studies at Ukrainian Folk Songs". Thus N. Hryhorash writes - the socio-cultural, translation-publishing, research, and literarycritical activity of I. Franko aimed at Ukrainian-Bulgarian unification is launched (Григораш, 2007, с.91). M. Maliarchuk draws attention to the extraordinary efforts exerted by I. Franko while researching the borrowed proverbs in Ukrainian folklore and Ukrainian proverbs in that of other nations. Contrasting 500 Ukrainian proverbs with Bulgarian ones, I. Franko does not reveal external similarities, but a profound internal semantic equivalence between Ukrainian and Bulgarian proverbs. A deep, like that, understanding of the Bulgarian text occurs but seldom (Малярчук, 1964, с.270-271; Малярчук 1963; Малярчук 1965).

For this, with no exaggeration, titanic activity, the researchers rank I.Franko in a narrow circle of Slavonic scholars and his contemporaries (F. Miklošič, O. Potebnia, O. Pypin, O. Veselovsky, V. Jagić, A. Brückner) who constantly emphasized the connection between literature and professional culture in general, with popular folk sources. One can add another name to these famous Slavicists - that of M. Drahomanov - a proponent of the method aimed at researching Ukrainian folklore in a broad Eurasian context. I. Franko perceived his method. In a letter to M. Drahomanov he requests to acquaint him with the methodology of folklore research in Bulgaria, reporting on his own poem "Surka", written on the grounds of Bulgarian folklore (Григораш, 2007, c.91). I. Franko's theoretical corpora based on Bulgarian studies can be further subdivided into ten more, to say the least, e.g. apocryphal research (Григораш, 2007). Working on the apocrypha, I. Franko applies his literary research method, in which, as O. Chycherin aptly put it, a true philologist, linguist and brilliant translator, scholar-commentator merge with a critic-publicist responding to new phenomena in native and many foreign literatures (Чичерін, 1958, c.191). The material presented here does not, regrettably, exhaust the Bulgarian discourse of Ivan Franko, translation, as well as intertextual, comparative-literary, theoretical, publicistic aspects etc. (Теплий, 2017, c.224-238).

An important detail is furnished by P. Atanasov: the letter of M. Pavlyk to L. Drahomanova (dated 28 Sept. 1896) informs of I. Franko's awaiting the appointment as Head of the department of Slavic languages in Berne and intends to call at Sophia on his way there. However I. Franko was not appointed to this post and he did not visit Sofia (Атанасов, 1956, с.33).

I. Franko kept track, too, of T. Shevchenko's works in foreign-language translations, an example being the publication of "A Slovenian Translation of Shevchenko's Poetry", communicating, among other things: "In recent times, a Slovenian, Father Josif Abram, the pastor in Novaky (Primorje) has started translating them" (ЛНB, 1906, IX/ XXXIII, c.398), 
exemplified by the following text from the Haydamaky poem:Vse gré, vse minéva brez méj in odmora. / Kam li se je délo? Odkod se vzélo?/ Ni bébec ni módrec ne vé odgovóra (ЛНВ, 1906, IX/ XXXIII, c.398), which means "All flows and all passes - this goes on forever.../ Yet where does it vanish? And whence did it come? / The fool does not know, and the sage knows no better" (Taras Shevchenko, 2018. Tr. by John Weir).

Conclusions. The problem is, to sum it up, multifaceted, requiring more generalization, further study, primarily an analysis of translations, and provides a valuable material to cover the issue of I. Franko's creative method as translator, his linguistic personality, philosophical and cultural context of activity.

The translation discourse of this linguistic and cultural area includes: Serbian literature ( 2 authors, 12 works, 39 pages), Bulgarian (13 pages, 4 works), Bosnian-Herzegovinian poetry ( 2 works, 2 authors, 8 pages), Montenegrin literature (1 author, 1work, 10 pages).

The Serbian-language discourse is characterized by poetic, prose translations and literary-critical materials, in particular, the typology of plots, motifs of Ukrainian folk and Serbian hajduk and household songs. The creative interaction manifests enormous artistic energy, accumulated in the texts of culture. I. Franko as a translator of Serbian prose and poetry approaches the task in different ways, observing more rigorousness in the translation of poetry, less so - in that of prose. The Bulgarian-language discourse embraces only four translations, but a great number of important scholarly papers authored by I. Franko (at least 10 subdivisions (at low estimate), more than 10 papers/reviews, 15 pages of brief presentations etc.). The Bosnian-Herzegovinian and Montenegrin texts deal with translation, and may as such be described by analogy with those of Serbian literature.

\section{Список посилань}

Атанасов, П., 1956. Иван Франко и Болгария. Славяне: Ежемесячный журнал Славянского комитета СССР, 7. с.32-33.

Білоус, Л. Л., 2006. Духовна народна поезія сербів в перекладах Івана Франка. В: Б. Косановић, уред. Иван Франко и срби: Зборник радова са међународног симпозијума одржаног у Новом Саду 25-27. новембра 1996. Нови сад: Српско-украјинско друштво: Архив Војводине.

Гольберг, М. Я., 1962. Іван Франко і болгарська фольклористика. Тези доповідей Сьомої шуорічної наукової сесії, присвяченої вивченню творчості І.Я.Франка 7-9 вересня 1962 р. М. І. Рудницький, ред. Львів: Вид-во Львів. ун-ту, с.21-22.

Гольберг, М. Я., 1990 [Обговорення]. Іван Франко і світова культура: Матеріали міжнародного симпозіуму ЮНЕСКО (Львів, 11-15 вересня 1986): У 3-х кн./ Кн. 2. Б. З. Якимович, упоряд.; І. І. Лукінов, М. В. Брик, Г. Д. Вервес та ін., ред. Київ: Наук. думка.

Гольберг, М. Я., 2006. Виявлення українсько-сербських літературних взаємин: підсумки та перспективи. В: Б. Косановић, уред. Иван Франко и срби: Зборник радова са међународног симпозијума одржаног у Новом Саду 25-27. новембра 1996. Нови сад: Српско-украјинско друштво: Архив Војводине.

Григораш, Н., 2007. Украинската литературоведска българистика от XIX и средата на XX век: Личности и школи. Велико Търново: Университетско издателство “Св.св. Кирил и Методий”.

Гуць, М. В., 1966. Південнослов'янський гайдуцький епос та сербохорватська народна лірика в перекладах І. Я. Франка. В: М. В. Гуць. Сербохорватська народна пісня на Украӥні. Київ: Наукова думка. [online] Доступно: http//rastko.rs> rastko-ukr/au/ guc_pisnja_kn.html [Дата звернення 16 лютого 2017] 
Дмитрук, В., 1958. 3 історії українсько-болгарських зв’язків. Жовтень: Літературно-художній та громадсько-політичний журнал Спілки письменників України, 5, с.133-145.

Івашків, В., 2006. Іван Франко і сербські епічні пісні. В: Б. Косановић, уред. Иван Франко и срби: Зборник радова са међународног симпозијума одржаног у Новом Саду 25-27. Новембра 1996. Нови сад: Српско-украјинско друштво: Архив Војводине.

Йовович, Лука, 1898. Гайдуки. Образок із життя чорногорців. Перекл. І.Франка. Літературно-науковий вістник, 1, с.103-113.

Кремпа, І., 1956. Фольклористична діяльність Івана Франка. Дукля: Літературнохудожній та громадсько-політичний альманах. Орган украӥнських письменників Спілки словацьких письменників, с.17-26.

Лаћак, Ђ., 2006. Иван Франко и српска епска песма у оцени М. В. Гуца. В: Б. Косановић, уред. Иван Франко и срби: Зборник радова са међународног симпозијума одржаног у Новом Саду 25-27. Новембра 1996. Нови сад: Српско-украјинско друштво: Архив Војводине, с.114-118.

Літературно-науковий вістник, 1906. IX/ XXXIII.

Малярчук, Н. Д., 1965. Иван Франко - преводач на български народни песни. Известия на Института за литература, 1, с.61-90.

Малярчук, Н., 1963. Иван Франко и българската литература. Дисертационния труд за получаване на научните степени “кандидат на филологическите науки”.

Малярчук, Н., 1964. Българските пословици в научната дейност на Иван Франко. Известия на Етнографския институт и музей, 7, с.267-275.

Павличко, Д., 2006. Невмирущість у слові: Передмова. В: Антологія болгарської поезї / Перекл., передм., довідки про авт., прим. Д. Павличка. Київ: Вид-во Соломії Павличко “Основи”.

Прогласъ. [online] Доступно: https://en.wikipedia.org/wiki/Proglas -13 Spt. 2017.

Софийски държавен ун-т “Климент Охридски”. София, Болгария.

Теплий, I., 2017. Іншомовний дискурс Івана Франка: Форми реалізації: Монографія [Неопубліковане джерело]. Львів, с.224-238.

Уметничко вече посвећено Ивану Франку, 2006. В: Б. Косановић, уред. Иван Франко и срби: Зборник радова са међународног симпозијума одржаног у Новом Саду 25-27. Новембра 1996. Нови сад: Српско-украјинско друштво: Архив Војводине, c.207-208.

Франко I., 1980. Зібрання творів: У 50 m. Т.25. Із сербської літератури. Лаза Лазаревич. Біля кринииі. 3 життя сербської задруги. Київ: Наук. думка, с.457-470.

Франко І., 1986. Зібрання творів: У 50 m. Т.49. Лист до М. П. Драгоманова (Львів, 6 жовтня 1893 р.). Київ: Наукова думка, с.419-421.

Франко, І., 1899. Переклади Шевченка на сербську мову. Літературно-науковий вістник, 6 (6), с.188-189.

Франко, І., 1977. Зібрання творів: У 50 m. Т.10. Із болгарських пісень народних. Пісні гайдуцьккі. Київ: Наук. думка, с.73-85.

Франко, I., 1977. Зібрання творів: У 50 m. Т.10. Із сербохорватської народної поезії. Київ: Наук. думка, с.86-108.

Франко, І., 1980. Зібрання творів: У 50 m. Т.26. Новий сербський місячник “Стража”. Київ: Наукова думка, с.94-95.

Франко, I., 1980. Зібрання творів: У 50 m. Т.26. Сербські народні думи і пісні. Київ: Наук. думка, с.51-59. 
Франко, I., 1981. Зібрання творів: У 50 m. Т.32. Переклади Шевченка на сербську мову. Київ: Наукова думка, с.14-15, 468.

Франко, І., 1981. Зібрання творів: У 50 m. Т.32. Українська пісня в Сербії. Київ: Наукова думка, с.16-17.

Франко, I., 1984. Зібрання творів: У 50 m. T.41. Нарис історії украӥнсько-руської літератури до 1890 р. Київ: Наукова думка, 1984, с.194-470.

Франко, І., 1986. Зібрання творів: У 50 m. Т 49. Лист до М. П. Драгоманова ([Відень], 13 червня 1893 р.). Київ: Наукова думка, с.406-407.

Франко, І., 1986. Зібрання творів: У 50 m. T.46. Кн.2. Болгарські пращі М. Драгоманова. Київ: Наукова думка, с.24-42.

Франко, І., 1986. Зібрання творів: У 50 m. Т.50. Лист до Петко Тодорова (Львів, 20 груд. 1902 р.). Київ: Наукова думка, с.219.

Франко, І., 2008. Зібрання творів: У 50 m. Додаткові томи. Т.51. Із чорногорськой літератури. Лука Йовович. Гайдуки. Образок із життя чорногориів. Київ: Наукова думка, с.803-812; 947.

Франко, І., 2008. Зібрання творів: У 50 m. Додаткові томи. Т.52. Із сербської народної поезії. Київ: Наукова думка, с.727-728.

Франко, I., 2008. Зібрання творів: У 50 m. Додаткові томи. Т.52. Із боснійськогериеговинської народної поезії. Київ: Наукова думка, с.729-736.

Хајдуковић, Л., 2006. Франков превод Лазаревићеве приповетке На бунару. В: Б. Косановић, уред. Иван Франко и срби: Зборник радова са међународног симпозијума одржаног у Новом Саду 25-27. Новембра 1996. Нови сад: Српскоукрајинско друштво: Архив Војводине, с.128-136.

Чичерін, О. В., 1958. Літературознавчий метод Івана Франка в його судженнях про французьку літературу XIX ст. В: Іван Франко. Статті $і$ матеріали, 6, Львів: Видавництво Львівського університету, с.191-199.

Шевченко, Т., 2017. Нащо мені чорні брови? Перекл. з української К. Г. Андрусишена $і$ В. Кіркконнелла). [online] Доступно: http://taras-shevchenko.infolike. net/poem-song-whatuse-are-coal-black-brows-to-me- [Дата звернення 21 серпня 2017 р.]

Шевченко, Т., 2018. Гайдамаки. Перекл. Джона Вipa. [online] Доступно: https://taras-shevchenko.infolike.net/taras-shevchenko-poem-haidamaki-englishtranslation-by-john-weir.html [Дата звернення 2 березня 2018 p.]

Ярема, Я. Я., 2006. Хронологія життя $і$ творчості Івана Франка. Львів: Видавничий центр Львівського національного університету ім. Івана Франка.

\section{References}

A Soirée Dedicated to Ivan Franko. In: B. Kosanović, ed. Ivan Franko and the Serbs: Collected Papers from the International Symposium Held in Novi Sad, 25-27. Nov. 1996. Novi Sad: Serbian-Ukrainian Society: Vojvodine Archives, 2006, pp.207-208. (In Serbian)

Atanasov, P., 1956. Ivan Franko and Bulgaria. Slavianie [The Slavs]: Monthly journal of the Slavonic Committee of the USSR, 7, p.32. (In Russian)

Bilous, L. and L., 2006. Spiritual Folk Poetry of the Serbs in Ivan Franko's Translations. In: B. Kosanović, ed. Ivan Franko and the Serbs: Collected Papers from the International Symposium Held in Novi Sad, 25-27 Nov. 1996. Novi Sad: Serbian-Ukrainian Society: Vojvodine Archives, 2006, pp.119-127. (In Ukrainian) 
Chycherin, O. V., 1958. The Literary Research Method of Ivan Franko in His Reflections on $19^{\text {th }}$ c. French Literature. Ivan Franko. Articles and Materials, 6. L'viv: Vydavnytstvo L'vivs'koho universytetu, pp.191-199. (In Ukrainian

Dmytruk, V., 1958. From the History of Ukrainian-Bulgarian Relations. Zhovten': Literary-artistic and public-political magazine of the Union of Writers of Ukraine, 5, pp.133-145. (In Ukrainian)

Franko, I., 1899. Translations from Shevchenko into Serbian. Literary-Scientific Herald, 6 (6), pp.188-189. (In Ukrainian)

Franko, I., 1977. Collected Works: In 50 vols. Vol.10. From Bulgarian Folk Songs. Hajduk Songs. Kyiv, naukova dumka, pp. 73-85. (In Ukrainian)

Franko, I., 1977. Collected Works: In 50 vols. Vol.10. From Serbo-Croatian Folk Poetry. Kyiv, Naukova dumka, pp. 86-108. (In Ukrainian)

Franko, I., 1980. Collected Works: In 50 vols. Vol.26. Serbian Folk Dumas and Songs. Kyiv: Naukova dumka, pp. 51-59. (In Ukrainian)

Franko, I., 1980. Collected Works: In 50 vols. Vol.26. The New Serbian Monthly “Strazha". Kyiv: Naukova dumka, pp. 94-95. (In Ukrainian)

Franko, I., 1981. Collected Works: In 50 vols. Vol.32. Translations from Shevchenko into Serbian. Kyiv: Naukova dumka, pp.15-16, 468. (In Ukrainian)

Franko, I., 1981. Collected Works: In 50 vols. Vol.32. The Ukrainian Song in Serbia. Kyiv: Naukova dumka, pp.16-17. (In Ukrainian)

Franko, I., 1984. Collected Works: In 50 vols. Vol.41. An Outline on the History of Ukrainian-Ruthenian Literature Up Till 1890. Kyiv: Naukova dumka, pp.194-470. (In Ukrainian)

Franko, I. 1986. Collected Works: In 50 vols. Vol.46. Book 2. The Bulgarian Works by M. Drahomanov. Kyiv: Naukova dumka, pp.24-42. (In Ukrainian)

Franko, I., 1986. Collected Works: In 50 vols. Vol. 49. Letter to M. P. Drahomanov ([Vienna], 13 June 1893). Kyiv: Naukova dumka, pp.406-407. (In Ukrainian)

Franko, I., 1986. Collected Works: In 50 vols. Vol. 49. Letter to M. P. Drahomanov (Lviv, 6 October 1893). Kyiv: Naukova dumka, pp.419-421. (In Ukrainian)

Franko, I., 1986. Collected Works: In 50 vols. Vol. 50. Letter to Petko Todorov (Lviv, 20 Dec. 1902). Kyiv: Naukova dumka. (In Ukrainian)

Franko, I., 2008. Collected Works: In 50 vols. Additional Volumes. Vol 51. From Montenegrin Literature. Luka Jovović. The Hajduks. A sketch from the life of Montenegrins. Kyiv: Naukova dumka, pp.803-812, 947. (In Ukrainian)

Franko, I., 2008. Collected Works: In 50 vols. Additional Volumes. Vol 52. From Serbian Folk Poetry. Kyiv: Naukova dumka, pp.727-728.

Franko, I., 2008. Collected Works: In 50 vols. Additional Volumes. Vol 52. From Bosnian Herzegovinian Folk Poetry. Kyiv: Naukova dumka, pp.729-736. (In Ukrainian)

Holberg, M., 1962. Ivan Franko and Bulgarian Folklore Studies. In: M.I. Rudnyts'kyi, ed. Abstracts of the Reports for the Seventh Annual Scientific Session devoted to the study of I. Ya. Franko's works. September 7-9, 1962. L'viv, L'viv Univ. Press, pp.21-22. (In Ukrainian)

Holberg, M. Ya., 2006. The Revealing of Ukrainian-Serbian Literary Relations: Results and Prospects. In: . B. Kosanović, ed. Ivan Franko and the Serbs: Collected Papers from the International Symposium Held in Novi Sad, 25-27 Nov. 1996. Novi Sad: Serbian-Ukrainian Society: Vojvodine Archives, 2006, pp.164-165. (In Serbian) 
Hryhorash, N. Ukrainian Literary and Bulgarian Studies of the $19^{\text {th }}-$ mid $20^{\text {th }} \mathrm{cc.:}$ : Personalities and Schools. Veliko Turnovo: University Publishing House "St. Cyril and St.Methodius”, 2007, pp.89-107. (In Bulgarian)

Huts', M. V., 1966. South Slavonic Hajduk Epos and Serbo-Croatian Folk Lyrics in I. Ya. Franko's Translations. The Serbo-Croatian Folk Song in Ukraine. Kyiv: Naukova dumka. [online] Available at: rastko.rs〉 rastko-ukr/au/guc_pisnja_kn.html [Accessed 16 Feb. 1916] (In Ukrainian)

Ivashkiv, V., 2006. Ivan Franko and Serbian Epic Songs . In: . B. Kosanović, ed. Ivan Franko and the Serbs: Collected Papers from the International Symposium Held in Novi Sad, 25-27. Nov. 1996. Novi Sad: Serbian-Ukrainian Society: Vojvodine Archives, 2006. (In Serbian)

Khaiduković, L., 2006. Franko's translation of the short story by Lazarevic На бунару [By the Well]. B. Kosanović, ed. Ivan Franko and the Serbs: Collected Papers from the International Symposium Held in Novi Sad, 25-27 Nov. 1996. Novi Sad: Serbian-Ukrainian Society: Vojvodine Archives, 2006. (In Serbian)

Krempa I., 1956. The Folkloristic Activity of Ivan Franko. Duklia: Literary-artisitic and public-political almanac. Printed organ of Ukrainian writers at the Union of Slovak Writers, pp.17-26. (in Ukrainian)

Lachak, P., 2006. Ivan Franko and Serbian Epic Poems in M.V.Huts's Estimation. B. Kosanović, ed. Ivan Franko and the Serbs: Collected Papers from the International Symposium Held in Novi Sad, 25-27 Nov. 1996. Novi Sad: Serbian-Ukrainian Society: Vojvodine Archives, 2006. (In Serbian)

Literaturno-Naukovyi Vistnyk, 1898, 1; 1906, IX/ XXXIII. (In Ukrainian)

Maliarchuk, N., 1963. Ivan Franko and Bulgarian Literature: Diss. for Ph.D. (Philology) degree. Sofia, Sofia “Kliment Okhridski” State Univ., 1963. (In Bulgarian).

Maliarchuk, N., 1964. Bulgarian Proverbs in the Scientific Activity of Ivan Franko. Communications of the Ethnographic Institute and Museum, 7. pp. 270-271 (In Bulgarian)

Maliarchuk, N., 1965. Ivan Franko - translator of Bulgarian Folk Songs. Communications of the Institute of Literature, 6, pp. 61-90. (In Bulgarian)

Pavlychko, D., 2006. Immortality in the Word: Preface. Anthology of Bulgarian Poetry Transl., pref., notes on the authors, footnotes by D.Pavlychko. Kyiv, Osnovy Publishers of Solomiya Pavlychko. (In Ukrainian)

Proglas [online]. Available at: <https://en.wikipedia.org/wiki/Proglas> [Accessed 13 Sptember 2017].

Shevchenko, T., 2017. The Kobzar (Tr. from Ukrainian by Constantine Henry Andrusyshen and Watson Kirkconnell).[online] Available at: http://taras-shevchenko.infolike.net/poemsong-what-use-are-coal-black-brows-to-me- [Accessed 21 Aug. 2017].

Shevchenko, T., 2018. Haidamaki. Tr. by John Weir. [online] Available at: https://taras-shevchenko.infolike.net/taras-shevchenko-poem-haidamaki-english-translation -by-john-weir.html. [Accessed March 2 2018].

Teplyy, I., 2017. The Foreign-Language Discourse of Ivan Franko: Forms of Implementation: Monograph. [Unpublished source]. L'viv, pp.224-238. (In Ukrainian)

Yarema, Ya.Ya., 2006. The Chronology of Ivan Franko's Life and Creative Work. Lviv: The Publishing Centre of the Lviv Ivan Franko National University. (In Ukrainian) 


\title{
ПІВДЕННОСЛОВ'ЯНСЬКА ПРОБЛЕМАТИКА У ТВОРЧОСТI IBAНА ФРАНКА
}

\author{
Іван ТЕПЛИЙ \\ Львівський національний університет імені Івана Франка \\ вул. Університетська 1, Львів, 79000 \\ Кафедра іноземних мов для гуманітарних факультетів \\ e-mail: i_teplyy@yahoo.co.uk
}

Запропонована тема охоплює такі аспекти: науково-критичні праці, в яких порушуються вказані проблеми, перекладацький та перекладознавчий доробок на матеріалі цієї проблематики, образні аналогії та інші форми засвоєння іншомовного тексту, що їх розпрацював та активно впроваджував I. Франко. 3 огляду на це, постає важлива проблема інтертекстуальності.

У науково-критичних працях, написаних на матеріалі головно сербської, болгарської та чорногорської літератур, порушується низка проблем, як-от: переклади творів Т. Шевченка сербською та словенською мовами, коломийковий розмір у сербських та українських народних піснях. Ця подібність, на думку І. Франка, не випадкова, і варто б дошукуватися іiї джерел, у цьому сенсі привертають увагу статті “Сербські народні думи і пісні”, "Новий сербський місячник "Стража", "Пісні гайдуцькі”, "Болгарська університетська афера", "Болгарські праці М. Драгоманова” та ін. Важливим у цьому плані є й листування I. Франка. Все це підтверджує життєве кредо І. Франка - “бути чоловіком, освіченим чоловіком, не лишитися чужим у жаднім такім питанні, яке складається на зміст людського життя” (“Промова на 25-літньому ювілеї”).

Перекладацький доробок I. Франка у царині південнослов'янських літератур представлено у чотирьох томах [т.10, с. 86-108 (Із сербохорватської народної поезіі); т.25, с.457-470 (Із сербської літератури); т.51, с.803-812 (Із чорногорської літератури); т.52, с.727-728,729-736 (Із сербської народної поезії; із боснійськогерцеговинської поезії)], що становить 3 автори, 12 творів, 39 сторінок (сербська література), 2 автори, 2 твори, 8 сторінок (боснійсько-герцеговинська поезія), 1 автор, 1 твір, 10 сторінок (чорногорська література) - всього 57 сторінок. Сюди варто додати й поему “Сурка”, написану за мотивами болгарської народної творчості. Знайшовши в І. Франка глибокий аналіз “Прогласу” і використовуючи його підрядковий переклад, Д.Павличко зробив свій переклад-переспів цього геніального твору.

Отже, тема багатопланова, вимагає узагальнення, подальшого дослідження, насамперед аналізу перекладів і дає цікавий матеріал до висвітлення проблеми творчого методу I. Франка-перекладача, його мовної особистості, філософськокультурологічного контексту діяльності.

Ключові слова: славістика, переклад, рецепція, інтертекстуальність, творчий розвиток, образна аналогія, міжлітературні зв'язки, діяльність. 